\title{
A Study on Prospective School Counselors' Views on School Violence
}

\author{
Seda Donat Bacığlu*, Oya Onat Kocabıyık \\ Department of Guidance and Counseling, Faculty of Education, Trakya University, Turkey
}

Copyright(C2019 by authors, all rights reserved. Authors agree that this article remains permanently open access under the terms of the Creative Commons Attribution License 4.0 International License

\begin{abstract}
The aim of this study is to explore prospective school counselors' views on school violence and aggression by means of a news story reporting a case of school violence. The sample was comprised of 40 students (31 women and 9 men) studying in the Program in Guidance and Counseling in a Turkish state university, and enrolled in the elective course titled "Prevention of Violence and Aggression in Children and Adolescents" in 2016-2017 academic year. The course is available in the curriculum of the Program in Guidance and Counseling. Within the scope of the course, students have studied a newspaper article brought to the classroom by instructor. Then, based on this news story, prospective counselors were asked "to evaluate the school violence incident as a counselor working in that school" in the first place, and "to mention which intervention and prevention actions they could take as a counselor working in that school" in the second place. Students wrote their opinions on the paper. For descriptive analysis of data, interpretative phenomenological analysis - a qualitative research design - was used. Research findings were then discussed with regard to causes, consequences, and prevention of violence and aggression in children and adolescents with the related literature.
\end{abstract}

Keywords Violence, Aggression, Children and Adolescence, Counseling

\section{Introduction}

Violence is undoubtedly one of the main problems of today's societies. Violence refers to, in the narrow sense of the word, physical violence with its explicit and measurable qualities; but includes, in a broader sense, all forms of oppression that an individual experience whether it be direct or indirect, tangible or intangible. The most comprehensive definition of violence made by the World Health Organization (WHO) is as follows: "the intentional use of physical force or power, threatened or actual, against oneself, another person, or against a group or community that either results in or has a high likelihood of resulting in injury, death, psychological harm, maldevelopment, or deprivation" [75].

Violence is a multidimensional phenomenon, the cause of which is associated with numerous individual and social factors. Today, technological advancements, changes in social life, and consequences of phenomena such as war, terror and migration are among the factors that increase violence. Given the high rates of violence in societies, it is inevitable that violent and aggressive behaviors are common among children and adolescents. Considering that education system and schools build a bridge between children and young people, and the social, economic and cultural structure, it is of particular importance to focus on a number of issues including violence in schools, violence reproduced in schools, violent groups in schools, and mechanisms for resisting and preventing violence [37]. Children and young people spend the majority of their time in the school, and thus the school provides the opportunity to determine mental health needs of students immediately and ensures broader community outreach with regard to violence prevention and intervention [23].

Thus, in order to promote appropriate prevention and intervention strategies, it is important to develop a thorough understanding of causes and consequences of school violence. Violence prevention strategies intend to build an environment where the probability of violence is reduced, and the repetition of violence is prevented. In schools, interventions to prevent violence against children and adolescents are categorized into two, i.e. short-term and long-term strategies. Short-term strategies include environmental arrangements such as rearranging physical conditions in the school, taking safety measures, and assessing risk profile of the school, and school-administration-based strategies. Among long-term strategies are education- and program-based strategies and alternative extracurricular activities [71]. School counselors take on tremendous responsibility in the implementation of long-term strategies. According to the 
American School Counseling Association (ASCA), the school counselor's role includes preparing and implementing comprehensive developmental guidance programs that integrate prevention activities and short-term intervention and training to empower students. The programs cover preventive activities targeted at all students in the school and intervention activities for at-risk students. Schools develop and implement programs related to anger management, conflict resolution skills, peer mediation, social skills, and values education in consideration of students' developmental characteristics; informative programs for teachers with regard to classroom management, communication skills, conflict management, risk behaviors, and stress management, as well as related rules and procedures; informative programs for school administrators regarding leadership skills, school climate, crisis management, communication skills, conflict management, safety, and related legislation; informative programs for parents and families regarding communication skills, conflict resolution skills, stress management, and risk behaviors [7, 30, 33, 35, 60].

Furthermore, school counseling and guidance is required to include services for protecting students' mental health [20]. School counselors must be equipped with knowledge and skills required to work with students suffering from mental health issues [46]. That is why counseling education must include obligatory and elective components, both theoretical and applied, that help learners to gain competence to respond to real-life requirements effectively. Related studies based on counselors' views indicate that undergraduate programs in counseling and guidance provide students with theoretical knowledge, and that fail to furnish them with applied knowledge required to work in the field, but counselors are eager to foster their professional development once they enter work life $[32,42$, $65,72]$.

This study is based on the premise that it is of particular importance to incorporate theoretical and applied elective courses into undergraduate programs in counseling and guidance. School counselors must contribute to the prevention of violence and aggression as part of protective and preventive guidance services, especially considering that violence is quite common in today's world. The study, conducted in an elective course titled "Prevention of Violence and Aggression in Children and Adolescents", aims to examine - based on a news story about a case of school violence - prospective counselors' evaluation of violence and aggression, and intervention and prevention strategies they are likely to use when employed as a counselor.

\section{Materials and Methods}

\subsection{Research Model}

This study sets out to examine the meaning that prospective counselors attribute to the concept of violence. The interpretative phenomenological design was used to analyze written texts through which participants expressed their view about a case of school violence reported in a news story. The interpretative phenomenological analysis was preferred in this study as it is concerned with explaining possible meaning of a phenomenon, and allows participants to reveal their perception of a phenomenon $[2$, 59].

\subsection{The Sample}

This study was conducted with 40 prospective counselors ( 31 women and 9 men) studying in the Program in Guidance and Counseling in a Turkish state university, and enrolled in the elective course titled "Prevention of Violence and Aggression in Children and Adolescents" in 2016-2017 academic year. Purposive sampling method was used in this study with its potential to contribute to the explanation of violence [74]. Convenience sampling, a purposive sampling technique, was preferred. This is because it allowed the researchers to select subjects with convenient accessibility and proximity [51].

\subsection{Data-Collecting Instrument}

Data of this study were collected through document examination. In qualitative educational research, documents such as course plans, student assignments, student files and portfolios, classroom materials, school and student records and teacher assessment serve as a source of data [40]. As documents include materials such as records and texts, they are first examined, and then interpreted and recreated by researchers [6]. For the purpose of this study, research data were collected from prospective counselors' written evaluation of a news story that reports a case of aggression and violence.

\subsection{Data Collection}

The objectives of "Prevention of Violence and Aggression in Children and Adolescents", an elective course offered in the third year of the Program in Guidance and Counseling, are to define concepts of aggression and violence based on theoretical approaches, to examine causes and consequences of violence, and to determine measures that can be taken to prevent aggression and violence among children and young people. The course content includes the definition of aggression and violence, theoretical approaches, causes and consequences of violence, frequency and types of violence observed among children and young people, and prevention of violence. The fourteen-week course concentrated on these topics, and required students to discuss violence through question-and-answer sessions and case studies. After students mastered the course content, the instructor brought to the classroom, as a case 
study, a news story (of April 8 2016) regarding a high school student that knifed his peers during a fight in a soccer game. The instructor shared this news with students without making any comments about it. Then, based on this news story, prospective counselors were asked "to evaluate the school violence incident as a counselor working in that school" in the first place, and "to mention which intervention and prevention actions they could take as a counselor working in that school" in the second place. Students were provided with information about the research, and were asked to take part in the research on a voluntary basis. The data of this study were what prospective counselors wrote about school violence.

\subsection{Data Analysis}

Interpretative phenomenological analysis - a qualitative research model - was used for descriptive analysis of data [57]. Data analysis was conducted according to the "interpretative phenomenological analysis" method used by Smith, Jarman, and Osborn [58]. The following procedures were followed:

The initial stage involved reading the transcripts/texts carefully, and rereading them in different times to avoid any misunderstanding. This stage helped the researchers to identify meaningful textual units created by prospective counselors. Meaning units that capture the essence of participants' words were identified and listed. This procedure was followed for the entire transcript/text. The researchers then started over reading the first transcript to identify emergent themes. The initial notes were transformed into emergent themes for the entire transcript
[58].

In the second stage, the researchers sought relationships between themes and clustered themes. They compared and checked whether these themes represented what prospective counselors originally said. In the third stage, the researchers read over the other transcripts to identify meaningful units and then themes. They grouped themes under broader themes, i.e. superordinate themes, after analyzing each transcript through an interpretative process. In this process, new themes emerged. The themes tested in previous transcripts were transformed into new themes to obtain subthemes. In the final stage, a figure was drawn to show all the themes that emerged at the end of this process [58].

In order to foster reliability of the research, two faculty members were asked to check data analyses and themes, and to examine the concordance between data and themes. Two faculty members further compared judgments, interpretations and recommendations with raw data to ensure that findings can be confirmed. Participants' notes were quoted directly to ensure transferability of themes and subthemes obtained [5, 12]. In this study, "Maxqda 12" software was used in data analyses as it allows researchers to determine themes and subthemes efficiently, to build connections between themes with the retrieval function, and to draw a figure with the mapping function.

\subsection{Findings}

Five main themes were extracted as a result of data analyses, i.e. prejudice, definition, causes, evaluation, and prevention and intervention. Themes and subthemes are illustrated in Figure 1. 


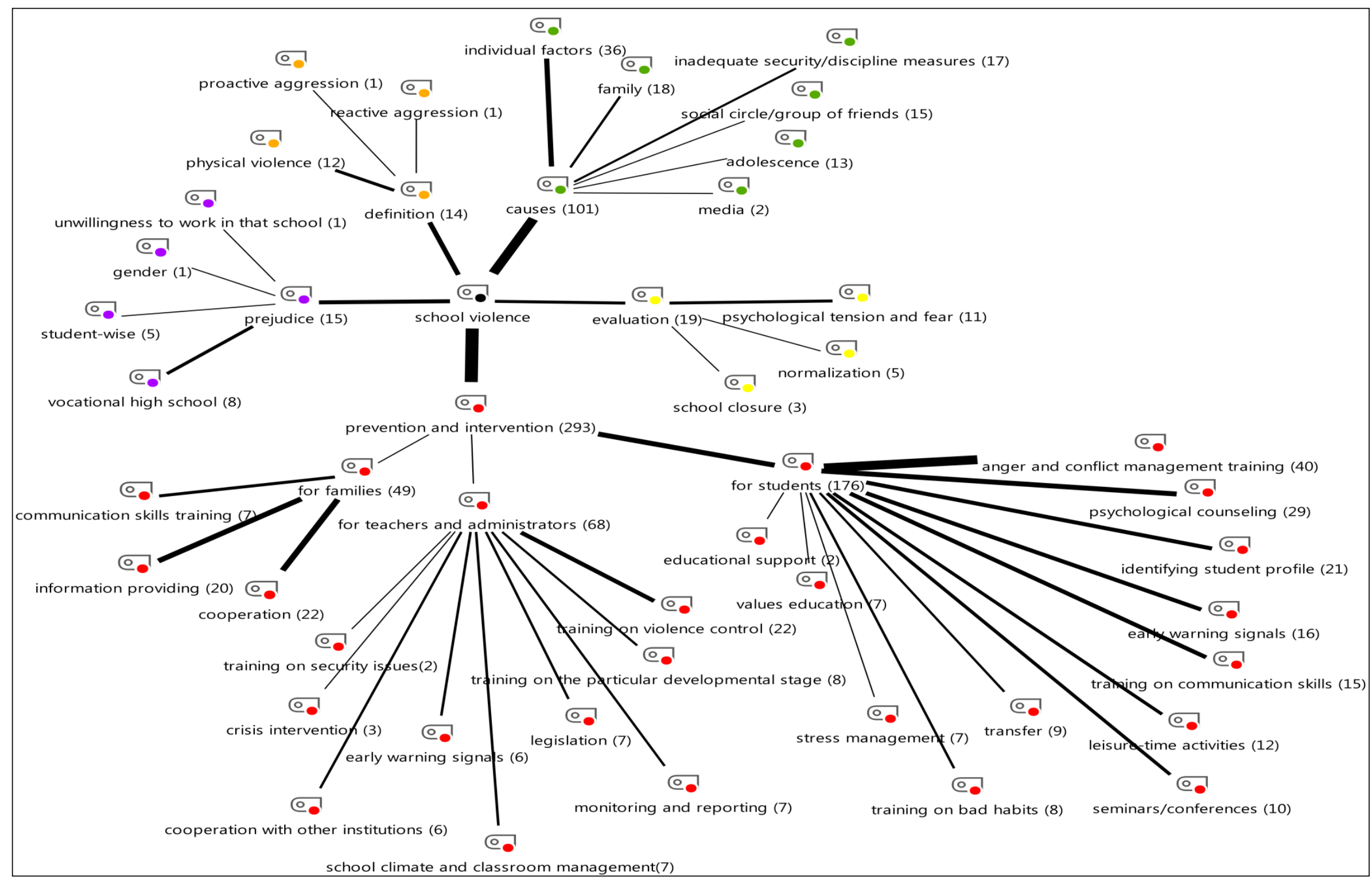

Figure 1. Themes Regarding the Meaning That Prospective Counselor Attribute to School Violence 


\subsubsection{Theme 1. Prejudice}

The prejudice theme indicates that prospective counselors' prejudices with regard to violent behaviors in the school focus on the following: "vocational high school" $(\mathrm{n}=8)$, "student-wise" $(\mathrm{n}=5)$, "gender" $(\mathrm{n}=1)$, and "unwillingness to work in that school" $(\mathrm{n}=1)$

The prejudice related to "vocational high school" is expressed as follows:

"Another point is that it is a vocational high school. Students in this type of school generally have lower academic performance, are problematic, known as "good-for-nothing", prone to violence, bring weapons to school, and have bad habits (S 29)."

The "student-wise" prejudice is associated with judgments indicating that the students can have a prior history of aggressive behaviors or are likely to display similar aggressive behaviors in the future.

"The student is likely to display violent behaviors towards not only friends but also family members when he becomes an adult. He can commit violence against his wife and children. He can marry off his kids at a very young age, and see no harm in that. For, he has probably been unloved as a kid. He would believe that what he does is right and is likely to produce positive outcomes (S 11)."

One of the students revealed as follows their "gender"-related prejudice:

"The majority of the group consisted of men. This may cause members to lord over each other, and thus lead to violence (S 25)."

Another student clearly indicated their prejudice about "unwillingness to work in that school".

"I definitely would not like to work as a counselor in that school (S 30)."

\subsubsection{Theme 2. Definition}

Under the definition theme, prospective counselors used the following definitions to refer to the aggressive behavior: "physical violence" ( $(\mathrm{n}=12)$, "proactive aggression" $(\mathrm{n}=1)$, and "reactive aggression" ( $\mathrm{n}=1)$

An example of "physical violence" definitions is as follows:

"With these feelings, he stabs Y.G. Not being able to control his anger and rage, he shows aggressive behaviors and perpetrates violence (S 9)."

The definition associated with "proactive aggression" is as follows:

"Proactive aggression is highly dangerous as the perpetrator is totally coldblooded (S 11)."

The "reactive aggression" definition made by one of the students is as follows:

"In this case, C.G. shows directly active and reactive aggression towards Y.G. Reactive aggression is a defensive act that occurs impulsively and probably due to a misunderstanding. A person attacks another one suddenly and reacts without thinking about consequences of their behaviors. C.G. showed reactive aggression. He got mad at Y.G., and attacked him impulsively and defensively (S 23)."

\subsubsection{Theme 3. Causes}

Prospective counselors referred to the following factors as causes of the aggressive behavior: "individual factors" $(\mathrm{n}=36)$, "family" $(\mathrm{n}=18)$, "inadequate security/discipline measures" $(\mathrm{n}=17)$, "social circle/group of friends" $(\mathrm{n}=15)$, "adolescence" ( $\mathrm{n}=13)$, and "media" $(\mathrm{n}=2)$.

"Individual factors" include lack of anger management, lack of conflict resolution skills, personality traits, unhealthy communication, and problems. Some examples of quotations that refer to individual factors as a cause of aggression are as follows:

"C.G. might have stabbed his friend because of a conflict arising from his belief that Y.G. humiliated him in front of others, or because he failed to control his sudden and impulsive anger (S 5)."

"We can say that he lacks conflict resolution skills (S 34)."

"I believe he has low self-esteem, ignores social values, has adaptation problems, and displays aggressive behaviors (S 14)."

"Another cause of this (aggression) is certainly lack of communication. Communication gets weaker and loses its importance in the society and schools. Empathy increasingly loses its function (S 18)."

"Furthermore, the student stabbed without thinking (about what will happen as a result). This indicates that his mental state or health was not good (S 27)."

"Family" is also defined as a cause of aggressive behaviors. Under the subtheme of family, prospective counselors referred to role modeling function of family, domestic violence, negligence in the family, and low socioeconomic and educational level of the family. Some examples of their expressions are as follows:

"They (families) must be a positive role model. Children mimic them. It is likely that when children experience violence, they see it as a solution (S 7)."

"Individuals that show such aggression generally tend to misunderstand a social behavior, attribute hostile intentions to it, or perceive unclear stimulants or behaviors. It is likely that students that display these behaviors were exposed to domestic violence (S 13)."

"Aggression was probably a manifestation of violence. As indicated by the fact that Y.G. had no control of anger and was carrying a sharp object on him... His family was probably neglecting him; his father - a role model - may also be prone to violence (S 16)."

"I think that the socioeconomic and educational level of these students' families is probably low. Children of such families are more inclined to commit crime (S 40)."

Another cause of violence that prospective counselors 
mentioned is "inadequate safety/discipline measures":

"What primarily draws attention in this incident is that two students got angry and came into conflict for no reason. Then it makes me question how a student could bring a knife to school, and the adequacy of security measures (S 3)."

Prospective counselors further referred to the impact of "social circle/group of friends" on the emergence of aggressive behaviors:

"It seems possible that the student that perpetrated violence had risen to the bait of a friend, and stabbed that guy outrageously (S 8)."

Prospective counselors argued that one of the factors behind violence might be "adolescence", drawing attention to developmental characteristics in adolescence:

"The incident occurred in a high school. Thus, students of this school are adolescents. This stage of development is the period during which violent and aggressive behaviors are the most common (S 27)."

One of the prospective counselors touched upon the impact of "media" on the emergence of violence:

"There may be many causes of violence. However, we should keep in mind that encouraging violence is by no means uncommon in the society. For example, TV shows all include fight, vandalism and murder. Children, watching these shows, put into practice what they see on the screen. They think this is a normal behavior (S 30)."

\subsubsection{Theme 4. Evaluation}

With respect to the evaluation theme, prospective counselors evaluate the results of an aggressive behavior as "tension and fear" $(\mathrm{n}=11)$, "normalization" $(\mathrm{n}=5)$, and "school closure" $(\mathrm{n}=3)$.

One of the students made the following evaluation regarding "psychological tension and fear":

"It is likely that students witnessing the incident were affected psychologically. The police and other students started fighting with each other after the student that stabbed his friend ran away. Other students might have displayed aggressive behaviors with the shock and tension of this incident, seeing a student severely wounded (S 14)."

Prospective counselors also linked increasing aggression and violence to "normalization" of aggressive and violent behaviors. Normalization is an outcome of the process through which people start to commit violence easily in front of other people. Following evaluation of a student underlines this fact:

"If one can perpetrate violence in a school in front of everybody, this means that violence is perceived as a means of problem-solving, and has already become a life style (S 12)."

Evaluating the incident violence, prospective counselors mentioned that it was a right decision to close the school for a couple of days:
"It was a right decision to close the school, and by doing so, to allow some time for students to get over it and for staff to take control of the situation (Ö 14)."

\subsubsection{Theme 5. Prevention and Intervention}

Prospective counselors stressed that there is a need to carry out prevention and intervention activities and programs targeted at "students", "teachers and administrators" and "families" with a view to preventing violence and managing the process in case of violence.

With regard to activities for "students", prospective counselors referred to anger and conflict management training $(n=40)$, counseling $(n=29)$, identifying student profile $(n=21)$, early warning signals $(n=16)$, training on communication skills $(n=15)$, leisure-time activities $(n=$ 12), seminars/conferences $(n=10)$, transfer $(n=9)$, training on bad habits $(n=8)$, stress management $(n=7)$, values education $(n=7)$, and educational support $(n=2)$. Examples of their recommendations are as follows:

"I would try to deliver training on anger control and conflict resolution (S 17)."

"I would offer individual counseling and group counseling (if facilities are available) for remaining students (S 11)."

"With respect to intervention, I would first make an overview of student profiles, i.e. family characteristics, status, personality traits, interests, talent, social circle, academic performance, socio-economic level, and so on (S 10)."

"Along with these, there is a need to pay attention to early warning signals. These signals include, for example, increased non-attendance and decline in academic performance (S 13)."

"There is a need for regular training programs and seminars related to communication skills and positive thinking (S 3)."

"I would carry out alternative activities, namely leisure-time activities, during which students concentrate on something else and channel their energy into purpose ( $S$ 26)."

"Furthermore, I would deliver seminars and conferences to make each individual gain awareness of violence, and its harms and consequences (S 30)."

"If the situation is more severe than a school counselor can handle, there is a need to seek other solutions to violence, e.g. referring the student to a psychiatrist or psychologist, use of medications, behavioral therapy, and psychological assistance (S 27)."

"Training on bad habits can prevent violence arising from habits such as drug addiction (S 15)."

"I would tell them how to cope with stress. Stress leads to anger, and anger leads to violence (S 7)."

"Delivering values education, we can teach them loving people and giving value to people, and by doing so, help them not to hurt each other (S 15)." 
"I would assist them in revealing their talent. I would carry out activities to promote their academic success (S 38)."

With respect to prevention and intervention activities targeted at "teachers and administrators", prospective counselors' viewpoints focus on the subthemes of training on violence control $(n=22)$, training on the particular developmental stage $(n=8)$, monitoring and reporting $(n=$ $7)$, legislation $(n=7)$, school climate and classroom management $(n=7)$, early warning signals $(n=6)$, cooperation with other institutions $(n=6)$, crisis intervention $(n=3)$, and training on security issues $(n=2)$. Some examples are provided below:

"Informing administrators and teachers about coping with stress, preparing violence training program in the school, and so on (S 21)."

"I would inform them about individuals' developmental characteristics and adaptation problems they are likely to encounter (S 12)."

"I would focus on supervision, monitoring and reporting, and carry out related activities with teachers and administrators (S 24)."

"They need to be informed about the legislation. If they know what constitutes a crime, then they can follow legal procedures (S 24)."

"I would inform them about the school climate and classroom management (S 23)."

"I would inform them and raise awareness about early warning signals (S 34).”

"I would inform them about institutions from which we can request help (S 23)."

"I would inform teachers and administrators about crisis intervention (S 26)."

"There is a need to deliver training on security measures to be taken in the school, and which procedures to follow in case of a problem (S 3).,"

With respect to violence prevention and intervention activities targeted at "families", prospective counselors mentioned cooperation $(n=22)$, information providing $(n=$ $20)$, and communication skills training $(\mathrm{n}=7)$.

"We must meet and cooperate with the family to get information about which behaviors the student displays at home, his/her personality traits, whether he/she has experienced domestic violence, who his/her role model is (if any), how he/she solves problems, and his/her communication with the family (S 25)."

"Therefore, there is a need to hold information meetings, sessions and symposiums for families to provide them with information about how to protect children from risk factors (S 18)."

"The family is also a stakeholder. Especially training programs for families with adolescents can inform them on how to and how not to behave towards their children (S 5)."

\section{Conclusions}

This section provides an explanation and interpretation of research results in the light of the related literature. The discussion of results herein follows the order they are presented in the "Findings" section. The first theme, prejudice, showed that prospective counselors have prejudices with regard to "vocational high school", "students", "gender", and "unwillingness to work in that school". In the literature, there are findings suggesting that the incidents of aggression and violence are more common in vocational high schools [67], and that gender is one of the factors behind aggression and the rate of violence is higher among men than women $[3,11,14,21,38]$. These results apparently support prospective counselors' prejudices about aggression and violence. However, it should be noted that such prejudices do not comply with the requirements of psychotherapy, namely unconditional acceptance, empathy and transparence, and qualifications expected from an effective counselor.

Prospective counselors' views related to students of vocational high schools and the students that commit violence, and unwillingness to work in such a school are of particular concern. There are problems related to vocational high schools considering that, in Turkey, students are placed to technical and vocational schools according to their examination score in the selection and placement system [27]. School-related prejudices are, nevertheless, not desirable in counseling education as they indicate incompliance with the multicultural approach, and reflect the general public inclination to label those who commit crime [10]. Multicultural counseling competence is of particular importance and one of the most debatable issues in the counseling profession [8]. Students can gain multicultural counseling competence in applied as well as theoretical courses in the program. One of the ways of enabling prospective counselors to gain this competence is encouraging them to work with people from different cultural backgrounds [31].

The second emergent theme is how prospective counselors define aggressive behavior. The majority of prospective counselors referred only to the aspect of "physical violence" when interpreting the news story. Studies related to aggressive behaviors have historically focused on overt physical aggression [3]. Focus only on the physical aspect narrows down the definition and scope of violence. Violence includes not only actions targeted at body and physical materials but also acts that affect an individual's psychological condition and threaten their mental health [24]. Physical aggression and verbal aggression that constitute behavioral components of violence are highly correlated with each other [11] while emotional/psychological violence coexists in any form of violence.

The third theme is related to prospective counselors' views on the causes of aggressive behaviors. Among 
"individual factors" behind violence, prospective counselors referred to lack of anger management, lack of conflict resolution skills, personality traits, unhealthy communication, and psychological problems. In the literature, the individual factors that lead to aggression and violence include social and emotional challenges, low self-esteem [41]; low tolerance in case of disappointment, failure in coping with frustration, weak social skills [69]; insufficiency of life skills such as conflict resolution, problem solving, and communication [16] and personality disorders and behavioral disorders.

Along with individual factors, prospective counselors mentioned "family and social circle" as factors behind aggression and violence. Family-related causes of violence include methods of childrearing, insufficient control over children, lack of adequate social support, failure in being a role model, and domestic violence [22, 25, 47, 64]. With respect to "inadequate security and discipline measures", it is reported that violence is less common in schools where students are involved in decision-making processes, rules are implemented clearly and consistently, and sense of belonging to school is high $[13,18,43,44]$. The use of security technologies has been increasing in schools. Although physical measures and arrangements such as the use of metal detectors and security cameras are not the only security solutions, when used appropriately, these measures are still important for reducing security and discipline problems and intervening in an incident immediately [19, 29].

Prospective counselors also referred to "social circle/group of friends" and "media" as causes of violence. In their study, Özcebe, Çetik, and Üner (2006) found out that children and young people are more inclined to commit violence in the school and against their friends [47]. With regard to social circle, there are studies showing that the factors behind violence include the environment in which a child lives, culture, role models, bad education, unfavorable housing conditions, immigration, technology, and bad habits [4, 36, 39, 49]. Studies focusing on the relationship between media and violence suggest that media plays an important role in increasing violence. In Özgür et al.'s (2011) study, the majority of students reported that they learnt violence from print and visual media [50]. Altun and Baker (2010), seeking the causes of violence from teachers' perspective, found out that program with violent media content is among the factors that provoke violence. These findings support results of the present study with respect to causes of aggression and violent behaviors [1].

In this study, prospective counselors further drew attention to the factor of "adolescence" as a cause of violence and aggression. Adolescence is a period during which individuals need to get adapted to a number of transformations in bodily, sexual and cognitive terms. Some adolescents, after getting through unexceptional challenges, build their identity and develop a positive self-concept, and transfer to adulthood; while some adolescents undergo a more difficult process and have to cope with several problems including youth crime, drug use, suicide, behavioral disorders, and mental health problems [55]. Participants of the present study took courses related to development, stages of life, and adaptation problems in the undergraduate program. The study results lead us to consider that these courses enabled students to have full understanding of adolescence and build a relationship between adolescence, and violence and aggression.

The fourth theme, evaluation, is related to how prospective counselors evaluate the situation that occurs as a result of an aggressive and violent behavior. Prospective counselors believe that violence commonly leads to "psychological tension and fear". Acts of violence jeopardize trust in society, and provoke emotions that challenge emotional and mental health, e.g. fear, anxiety, disappointment, and stress [36]. Occurrence of violence and "school closure" because of violence are likely to cause depression and anxiety among other members of the school. Students may have difficulty in concentrating on studying, and take a dislike to school and be more inclined to absenteeism. Violence may also lead to loss of workforce and long-term psychological problems among teachers [36]. This result points to the need for empowering school counselors so that they facilitate the process of coping with negative emotions and behaviors arising from violence.

With regard to the fifth theme, i.e. prevention and intervention, prospective counselors drew attention to prevention and intervention activities targeted at "students", "teachers and administrators", and "families". Yeşilyaprak (2006) notes that the most fundamental and radical way of stopping school violence is to create a safe school environment that responds to developmental needs of children and young people, and in which they express themselves freely and get respect [73]. There is an urgent need to implement intervention program for students and their families in order to ensure that children and young people adopt nonviolence [45]. Pişkin, Öğülmüş, and Boysan (2011) underline the need to create a team consisting of school administrators, teachers and families, and to include all education stakeholders into the process of struggle against violence [53]. School counseling and guidance services must include not only children that are victims of violence but also children that perpetrate violence and their families [20]. Thus, a holistic approach, which engages students, teachers, administrators and families, must be adopted in developing prevention and intervention activities and programs.

Extant literature shows that prevention and intervention activities for students with respect to school violence and violent behaviors focus on anger management [33, 60, 61 26], conflict management [7,35], counseling [15,48], identifying student profiles and risk groups, and identifying 
early warning signals $[4,45]$, communication skills training [9], leisure-time activities [34], seminars/conferences, referral, training on bad habits, stress management [62], values education [28], and educational support, which all complement findings of the present study. School-based activities include programs for teachers and administrators [57, 70], and programs for families [6, 35, 52]. Meta-analyses conducted in Turkey and abroad [17, 54, 63, $66,68]$ indicate that such prevention and intervention programs reduce violent and aggressive behaviors among children. This result stresses that counselors must be equipped with skills required to plan and implement prevention programs in professional life.

This study, conducted in an elective course titled "Prevention of Violence and Aggression in Children and Adolescents", aimed to ensure that prospective counselors gain (theoretical and applied) knowledge and skills, as well as awareness, with regard to the concepts of violence and aggression, theoretical approaches to aggression, causes and consequences of aggression and violence, forms of violence, and violence prevention and intervention. Subsequently, based on a case of school violence, the researchers intended to seek the meanings prospective counselors attribute to violence by means of written notes where they expressed emotions and thoughts about violence. Considering the prevalence of violence, the results confirm that it is important to incorporate theoretical and applied elective courses on protective and preventive guidance into undergraduate and graduate programs in counseling, i.e. a discipline essentially related to mental health. The meaningful strategies which were identified may be consolidated and organized to serve as a basis for a revitalized guidance program or an enhancement of an existing well- defined intervention program. The sample of this study was restricted to prospective counselors in the third year of their study, taking the course "Prevention of Violence and Aggression in Children and Adolescents". A cross-sectional study may be conducted when the same students are in the fourth year of study in order to test whether there is any difference in their perception of violence. The same study may also be conducted with fourth-year students in the program. A further study may include prospective counselors from different universities for comparison purposes. However, more cases may be used to provide students adequate opportunities to explore and discover possible interventions for them to strategically plan for an enrichment of an existing guidance program or propose a new one.

\section{REFERENCES}

[1] Akbaba-Altun, S., \& Erdur-Baker, Ö. (2010). School violence: a qualitative case study. Procedia-Social and
Behavioral Sciences, 2(2), 3165-3169.

[2] Annells, M. (2006). Triangulation of qualitative approaches: hermeneutical phenomenology and grounded theory. Journal of Advanced Nursing, 56(1), 55-61.

[3] Arslan, C., Hamarta, E., Arslan, E., Saygın, Y. (2010). An investigation of aggression and interpersonal problem solving in adolescents. Illköğretim Online, 9(1), 379-88.

[4] Avcı M. (2008). Tutuklu çocuklar üzerine bir araştırma: çocukların suça yönelmesinde etkili olan toplumsal nedenler ve çözüm önerileri. Atatürk Üniversitesi Sosyal Bilimler Enstitüsü Dergisi, 11(1): 49.

[5] Baker, C., Wuest, J., \& Stern, P.N. (1992). Method slurring: the grounded theory/ phenomenology example. Journal of Advanced Nursing, 17, 1355-1360.

[6] Baş, T., \& Akturan, U. (2008). Nitel araştırma yöntemleri NVivo 7.0 ile nitel veri analizi. Ankara: Seçkin Yayıncılık.

[7] Bedel, A., \& Arı, R. (2011). Kişiler arası sorun çözme beceri eğitiminin yetiştirme yurdunda yaşayan ergenlerin yapıcı problem çözme ve sürekli öfke düzeylerine etkisi. Pegem Ĕ̌itim ve Öğretim Dergisi, 1(4), 1-10.

[8] Bektaş, Y. (2006). Kültüre duyarlı psikolojik danışma yeterlikleri ve psikolojik danışman eğitimindeki yeri.Ege Eğitim Dergisi, 7(1), 43-59.

[9] Beşer, N., \& Çam, O. (2008). Suça yatkın ergenlerde olumlu kişilerarası ilişkiler geliştirme programının etkinliğinin incelenmesi. Anatolian Journal of Psychiatry, 10, 226-232.

[10] Bilgiç, Ş. (2014). Mahkûmların suç algısı. Karamanoğlu Mehmet Bey Üniversitesi Sosyal ve Ekonomik Araştırmalar Dergisi, 16(Özel say1 1), 8-17.

[11] Buss, A.H., Perry, M. (1992). The Aggression Questionnaire. J Pers Soc Psych, 63: 452-9.

[12] Corbin, J., \& Strauss, A. (1990). Grounded theory research: procedures, canons, and evaluative criteria. Qualitative Sociology, 13, 1, 3-20.

[13] Çalık, T., \& Kurt, T. (2010). Okul iklimi ölçeğinin (OİÖ) geliştirilmesi. Eğitim ve Bilim, 35, 167-180.

[14] De Wied, M., Branje, S. J. T., \& Meeus, W. H. J. (2007). Empathy and conflict resolution in friendship relations among adolescents. Aggressive Behavior, 33, 48-55.

[15] Demir, M., \& Bademci, Ö.H. (2016). Suça sürüklenmiş bir gencin bakış açısıylaçocuk suçluluğu: Olgu sunumu. Atatürk Üniversitesi Sosyal Bilimler Enstitüsü Dergisi, 20 (1), 17-26.

[16] Dodge, K.A., \& Frame, C.L. (1982) Social cognitive biases and deficits in aggressive boys. Child Development,53, 620-635.

[17] Donat-Bacıŏlu, S. (2014). Şiddet ve Saldırganlığın Azaltılmasında Önleme ve Müdahale Programlarının Etkililiği: Meta Analiz Çalışması. Türk Psikolojik Danışma ve Rehberlik Dergisi, S. 5 (42), 294-304.

[18] Dönmez, B., \& Özer, N. (2009). Yöneticiler, öğretmenler, ögrenciler ve veliler için okul güvenliği ve güvenli okul. Ankara: Nobel.

[19] Dönmez, B., \& Özer, N. (2010). Güvenlik kamera 
sistemlerinin yönetici ve öğretmen görüșlerine göre değerlendirilmesi. Kuram ve Uygulamada Ĕ̆itim Yönetimi, $16(2), 215-230$

[20] Durmuș, E. (2013). Ergen bakıș açısıyla okulda şiddet ve çözüm önerileri. E-International Journal of Educational Research, 4(3), 41-57.

[21] Efilti, E. (2006). Ortaöğretim kurumlarında okuyan öğrencilerin saldırganlık, denetim odağı ve kişilik özelliklerinin karşılaştırmalı olarak incelenmesi. Yayımlanmamış Doktora Tezi. Selçuk Üniversitesi, Sosyal Bilimler Enstitüsü.

[22] Farrington, D.P. (2000). Epidemiology of juvenile violence. Child and Adolescent.Psychiatric Clinics of North America, 9(4), 733-748

[23] Froeschle, J., \& Moyer, M. (2004). Just cut it out: Legal and ethical challenges in counseling students who selfmutilate. Professional School Counseling, 7, 231-235.

[24] Gökulu, G. (2013). Basında kadına yönelik şiddet haberlerinin analizi: Hürriyet, Sabah ve Posta gazeteleri örneği (2005-2008). International Journal of Social Science, 6(2), 1829-1850.

[25] Güleç, H., Topaloğlu, M., Ünsal, D. ve Altıntaş, M. (2012). Bir kısır döngü olarak şiddet. Psikiyatride Güncel Yaklaşımlar, 4(1), 112-137

[26] Gültekin, F. (2011). İlköğretim ikinci kademe öğrencilerinin öfke ve saldırganlık düzeylerinin azaltılması. Hacettepe Üniversitesi Eğitim Fakültesi Dergisi, 41, 180-191.

[27] Günbayı, İ., \& Tokel, A. (2014). Teknik ve meslek liselerinde meslek derslerinin etkiliğine ilișkin yönetici, öğretmen ve öğrenci görüşleri. Eğitim ve Öğretim Araştırmaları Dergisi, 3(4), 59-73.

[28] Hökelekli, H. (2007). Çocuk ve gençlerde şiddet olgusu ve önlenmesine yönelik öneriler. Değerler Ĕgitimi Dergisi, $5(14), 61-78$

[29] İnand1, Y \& Yıldız, S. (2014). Lise okul yöneticilerinin okullarda şiddeti önleme yeterlikleri: Mersin İli örneği. Trakya Üniversites, Eğitim Fakültesi Dergisi, 4(2), 137-147.

[30] Kabasakal, Z. (2013). The effects of mother education programs on the functionality, anger management and conflict solution levels of families. Eurasian Journal of Educational Research, 52, 1-20.

[31] Kağnıcı, Y. (2013). Çok kültürlü psikolojik danışma eğitiminin rehberlik ve psikolojik danışmanlık lisans programlarına yerleştirilmesi. Türk Psikolojik Danışma ve Rehberlik Dergisi, 5 (40), 222-231.

[32] Karataş, Z., \& Baltac1-Şahin, H. (2013). Ortaöğretim kurumlarında yürütülen psikolojik danışma ve rehberlik hizmetlerine yönelik okul müdürü, sınıf rehber öğretmeni, öğrenci ve okul rehber öğretmeninin (psikolojik danışman) görüşlerinin incelenmesi. Ahi Evran Üniversitesi Kırşehir Eğitim Fakültesi Dergisi, 14(2), 427-460.

[33] Kaya, F., \& Buzlu, S. (2016). Suça sürüklenen çocuklara yönelik önleyici bir müdahale programı: Agresyon Replasman Eğitimi.Journal of Psychiatric Nursing, 7(3), $148-151$.

[34] Kılıç, M. (2011). Serbest zaman etkinliklerinin (rekreasyonun) çocuk suçluluğunun önlenmesindeki işlevinin incelenmesi. 1. Türkiye Çocuk Hakları Kongresi, Yetișkin Bildirileri Kitab1-2, 106-117.

[35] Kılıçarslan, S., \& Atıcı, M. (2017). Ergenlerde görülen saldırgan davranışlarda ebeveyn ve ergenlere uygulanan psikoeğitim programının etkisinin incelenmesi. Adnan Menderes Üniversitesi, Sosyal Bilimler Enstitüsü Dergisi, 4 (1), 20-41.

[36] Köknel, Ö. (2000). Bireysel ve toplumsal şiddet. 2. Basım. İstanbul: Altın Kitaplar Yayınevi.

[37] Kural Tural, N. (2006). Okul kültürü içinde şiddet. Toplumsal Bir Sorun Olarak Şiddet Sempozyumu, Eğitim Sen Yayınları, 237-239.

[38] Kuruöz, M., \& Koç, M. İlköğretim İkinci Kademe Öğrencilerinin Karşılaştıkları Engeli Aşmada Saldırganlığg Kaynak Görme Düzeyi, XVI. Ulusal Eğitim Bilimleri Kongresi, 5-7 Eylül, 2007, Tokat

[39] Menteşe, S. (2012). Sosyo-kültürel ve fiziki mekânların çocukların suça yönelme ya da suç işlemeye etkilerinin Van Ili ölçeğinde araştırması. Gaziantep University Journal of Social Sciences, 11(4), 1275- 1305.

[40] Merriam, S. B. (2009). Qualitative Research: A Guide to Design and Implementation: Revised and Expanded from Qualitative Research and Case Study Applications in Education. San Francisco: Jossey-Bass.

[41] Miller, G. E. (1994). School violence miniseries impressions and implications. School Psychology Review, 23(2), 257-261.

[42] Nazlı, S. (2007). Psikolojik danışmanların değişen rollerini algılayışları. Balıkesir Üniversitesi Sosyal Bilimler Enstitüsü Dergisi. 10(18). 1-17.

[43] Olweus, D. (2003). A profile of bullying at school Educational Leadership, 60(6), 12-17.

[44] Orpinas, P., \& Horne, M. A. (2006). Bullying prevention: Creting positive school climate and developing social competence. Washington: American Psychological Association

[45] Ögel, K., Tarı, I., \& Eke, C. Y. (2006). Okullarda Suç ve Şiddeti Önleme Kılavuzu. İstanbul, Yeniden Yayınları, No:7.

[46] Öz, F.S., Uzbaş, A., \& Aysan, F. (2016). Okul Psikolojik Danışmanlarının Psikolojik Danışma Yaklaşımlarına İlişkin Görüşleri. Türk Psikolojik Danışma ve Rehberlik Dergisi, 6(46), 53-69.

[47] Özcebe, H., Üner, S., \& Çetik, H. (2006). Adolesanlarda şiddet davranışları. Şiddet ve okul: Okul ve çevresinde çocuğa yönelik şiddet ve alınabilecek tedbirler Uluslar arası Katılımlı Sempozyum, İstanbul.

[48] Özdemir, M. B. (2015). Etkinlik temelli grupla psikolojik danışma müdahale programının çocuklarda öfke ve saldırganlığı azaltmaya yönelik etkileri. 21. Yüzyılda Ĕ̆itim ve Toplum, 221-236.

[49] Öztürk-Çopur, E., Ulutaşdemir, N. ve Balsak, H. (2015). Çocuk ve suç. Hacettepe Üniversitesi Sağlık Bilimleri Fakültesi Dergisi, 1(2), 120-124.

[50] Özgür, G., Yörükoğlu, G., \& Baysan-Arabac1, L. (2011). 
Lise öğrencilerinin șiddet algıları, șiddet eğilim düzeyleri ve etkileyen faktörler. Psikiyatri Hemşireliği Dergisi, 2(2), 53-60.

[51] Patton, M. Q. (2002). Qualitative research and evaluation methods. Thousand Oaks, CA: Sage.

[52] Pehlivan, H. (2008). Anne eğitim programının etkililiğinin değerlendirilmesi. Aile ve Toplum, 10(4), 55-66.

[53] Pişkin, M., Öğülmüş, S., \& Boysan, M. (2011). Güvenli okul ortamı oluşturma öğretmen ve yönetici kitabihttp://ancmtal.meb.k12.tr/meb iys dosyalar/41/02/76 1473/dosyalar/2016_09/15123827_guvenli_okul_ortami_ol usturma_ogrt_ve_yontc_kitabi.pdf, 03.01.2018 ${ }^{-}$tarihinde elde edilmiştir.

[54] Rigby, K. ve See, P. (2011). Interventions to reduce bullying. International Journal of Adolescent Medicine and Health, 20(2), 165-183.

[55] Savi, F. (2008). 12-15 yaş arası ilköğretim öğrencilerinin davranış sorunları ile aile işlevleri ve ana-baba kișilik özellikleri arasındaki ilişkisinin incelenmesi. Yayımlanmamış Doktora Tezi. DEÜ Eğitim Bilimleri Enstitüsü, İzmir.

[56] Sayın, U. (2014). 48-72 Aylık çocuklardaki saldırganlık davranışlarına müdahale yöntemi olarak ebeveyn eğitim programı geliştirilmesi ve etkililiğinin incelenmesi. Yayımlanmamış Doktora Tezi. Hacettepe Üniversitesi, Sağlık Bilimleri Enstitüsü.

[57] Smith, J. A., Flowers, P., \& Osborn, M. (1997). Interpretative phenomenological analysis and the psychology of health and illness. Material discourses of health and illness, 68-91.

[58] Smith, J. A., Jarman, M., \& Osborn, M. (1999). Doing interpretative phenomenological analysis. In E. Dans, M. Murray, \& K. Chamberlain (Eds.), Qualitative health psychology: Theories and methods (pp. 218-240). London: Sage.

[59] Smith, J. A., \& Eatough, V. (2007). Analysing Qualitative Data in Psychology. Edt. Lyons, E., \&Coyle, A. London: Sage Publications WHO. (2011). Violence Prevension Allience. Global Campaign for Violence Prevention.http://www.who.int/violenceprevention/approac $\mathrm{h} /$ definition/en/index.html

[60] Şekerci, B.G., Terzi, H., Kitiş, Y. ve Birimoğlu-Okuyan, C. (2017). Sekizinci sınıf öğrencilerine bilișsel davranıșçı yaklaşıma göre uygulanan öfke kontrol programının etkinliği. Dokuz Eylül Üniversitesi Hemsirelik Fakültesi Elektronik Dergisi,10(4), 201-207.

[61] Tekinsav Sütçü. S., Aydın, A., \& Sorias, O. (2010). Ergenlerde öfke ve saldırganlığı azaltmak için bilișsel davranışçı bir grup terapisi programının etkililiği. Türk Psikoloji Dergisi, 25(66), 57-67.

[62] Terzi, Ş. (2007). Okullarda yaşanan şiddeti önleyici bir yaklaşım: kendini toparlama gücü. Aile ve Toplum, 3 (12): 73-82.

[63] Ttofi, M.M., \& Farrington, D.P. (2010). Effectiveness of school-based programs to reduce bullying: a systematic and meta-analytic review. Journal of Experimental Criminology, 7(1), 27-56.
[64] Turan, M.T., \& Beşirli, A. (2008). Kentleşme sürecinin ruh sağlı̆̆ üzerine etkileri. Anadolu Psikiyatri Dergisi, $9,238-243$

[65] Tuzgöl-Dost, M. ve Keklik, İ. (2012). Alanda çalışanların gözünden psikolojik danışma ve rehberlik alanının sorunları. Mehmet Akif Ersoy Üniversitesi Eğitim Fakültesi Dergisi. 12(23), 389-402.

[66] Türk, F. \& Hamamcı, Z. (2016). Bilişsel-davranışçı yaklaşıma dayalı olarak uygulanan öfke kontrolü programlarının etkililiğinin değerlendirilmesi: Bir meta-analiz çalışması. The Journal of International Social Research, 9(43), 1522-1531

[67] Ünlü, A., Evcin, U., Burakgazi Yılmaz, H., \& Dalkılıc, A. (2013). The prevalence of crime and violence in Istanbul public high schools: comparison of school types. Anatolian Journal of Psychiatry, 14,152-60.

[68] Vreeman, R.C., \& Carroll, A.E. (2007). A systematic review of school-based interventions to prevent bullying. Arch Pediatr Adolesc Med., 161(1), 78-88.

[69] Weir, E. (2005). Preventing Violence in Youth. Canadian Medical Association Journal, 172 (10): 1291-1292.

[70] Yavuzer, Y., \& Üre, Ö. (2010). Saldırganlığı önlemeye yönelik psiko-eğitim programının lise öğrencilerindeki saldırganlığı azaltmaya etkisi. Selçuk Üniversitesi Sosyal Bilimler Enstitüsü Dergisi, 24, 389-405.

[71] Yavuzer, Y. (2011). Okullarda saldırganlık/şiddet: okul ve ögretmenle ilgili risk faktörleri ve önleme stratejileri. Milli Ĕ̈itim, 192. 43-61.

[72] Yerin-Güneri, O., Büyükgöze-Kavas, A., \& Koydemir, S. (2007). Okul psikolojik danışmanlarının profesyonel gelişimi: Acemilikten olgunlaşmaya giden zorlu yol. (Eds: R. Özyürek, F. Korkut Owen ve D. Owen), Gelișen psikolojik danışma ve rehberlik, meslekleşme sürecinde ilerlemeler, Cilt 1 (ss: 139-161). Ankara: Nobel Yayın.

[73] Yeșilyaprak, B. (2006). Toplumsal Bir Sorun Olarak Siddet Önlemede / Çözmede Psikolojik Danışma ve Rehberlik Hizmetlerinin Katkıs1. http://www.egitimsen.org.tr/down/si ddetsempozyum_303-306.pdf adresinden 03.01.2018 tarihinde elde edilmiştir.

[74] Y1ldırım, A., \& Şimșek, H. (2006). Sosyal Bilimlerde Nitel Araştırma Yöntemleri. Ankara: Seçkin Yayıncılık.

[75] WHO. (2011). Violence Prevension Allience. Global Campaign for Violence Prevention.http://www.who.int/viol enceprevention/approach/definition/en/index.html 